\title{
First record of Crypticerya zeteki (Cockerell, 1914) (Monophlebidae) in Brazil and Maconellicoccus hirsutus (Green, 1908) (Pseudococcidae) in the state of Maranhão
}

\author{
A. S. J. C. Ramos ${ }^{a}$, A. L. B. G. Peronti ${ }^{b}$, T. Kondo ${ }^{c}$ and R. N. S. Lemos ${ }^{a *}$ \\ aPrograma de Pós-graduação em Agroecologia, Universidade Estadual do Maranhão - UEMA, CP 9, CEP 65054-970, \\ São Luís, MA, Brazil \\ ${ }^{\text {b} D e p a r t a m e n t o ~ d e ~ F i t o s s a n i d a d e, ~ F a c u l d a d e ~ d e ~ C i e ̂ n c i a s ~ A g r a ́ r i a s ~ e ~ V e t e r i n a ́ r i a s ~-~ F C A V, ~ U n i v e r s i d a d e ~ E s t a d u a l ~ P a u l i s t a ~}$ \\ "Júlio de Mesquita" Filho - UNESP, CEP 14884-900, Jaboticabal, SP, Brazil \\ 'Laboratorio de Entomología, Corporación Colombiana de Investigación Agropecuaria - CORPOICA, \\ Centro de Investigación Palmira, Calle 23, Carrera 37 Continuo al Penal, Palmira, Valle, Colombia \\ *e-mail: rlemos@cca.uema.br
}

Received: April 14, 2016 - Accepted: September 2, 2016 - Distributed: February 28, 2018

(With 2 figures)

\begin{abstract}
Crypticerya zeteki (Cockerell, 1914) (Hemiptera: Coccomorpha: Monophlebidae) is recorded for the first time from Brazil and Maconellicoccus hirsutus (Green, 1908) (Hemiptera: Coccomorpha: Pseudococcidae) is recorded for the first time from the state of Maranhão, Brazil. Both species were collected from branches, leaves and fruits of various fruit trees in the municipalities of São José de Ribamar, São Luís and Paço do Lumiar, Maranhão, Brazil. Crypticerya zeteki was collected on Citrus spp. (Rutaceae), Cocos nucifera (L.) (Arecaceae), Cycas revoluta L. (Cycadaceae), Malpighia punicifolia L. (Malpighiaceae), Mangifera indica L. (Anacardiaceae), Musa paradisiaca L. (Musaceae) and Theobroma grandiflorum Schum (Malvaceae), all first records for this species. Maconellicoccus hirsutus was collected on Spondias tuberosa Arruda (Anacardiaceae) and M. punicifolia L. (Malpighiaceae), both new records for this species.
\end{abstract}

Keywords: biodiversity, mealybug, geographical distribution, Neotropical region.

\section{Primeiro registro de Crypticerya zeteki (Cockerell, 1914) (Monophlebidae) no Brasil e Maconellicoccus hirsutus (Green, 1908) (Pseudococcidae) no Maranhão, Brasil}

\begin{abstract}
Resumo
Crypticerya zeteki (Cockerell, 1914) (Hemiptera: Coccomorpha: Monophlebidae) é registrada pela primeira vez no Brasil e Maconellicoccus hirsutus (Green, 1908) (Hemiptera: Coccomorpha: Pseudococcidae) é registrada pela primeira vez para o estado do Maranhão, Brasil. Ambas as espécies foram coletadas em ramos, folhas e frutos de diferentes árvores frutíferas nos municípios de São José de Ribamar, São Luís e Paço do Lumiar, Maranhão, Brasil. Crypticerya zeteki foi coletada sobre Citrus spp. (Rutaceae), Cocos nucifera (L.) (Arecaceae), Cycas revoluta L. (Cycadaceae), Malpighia punicifolia L. (Malpighiaceae), Mangifera indica L. (Anacardiaceae), Musa paradisiaca L. (Musaceae) e Theobroma grandiflorum Schum (Malvaceae), todas registradas pela primeira vez para esta espécie. Maconellicoccus hirsutus foi coletado sobre Spondias tuberosa Arruda (Anacardiaceae) e M. punicifolia, ambos novos registros para esta espécie.
\end{abstract}

Palavras-chave: biodiversidade, cochonilha, distribuição geográfica, região Neotropical.

\section{Introduction}

The scale insect genus Crypticerya Cockerell (Hemiptera: Coccomorpha: Monophlebidae) comprises 27 species of which 15 are known from the Neotropical region. Some of these, e.g., C. brasiliensis (Hempel, 1900), C. genistae (Hempel, 1912) and C. multicicatrices (Kondo and Unruh, 2009; Kondo et al., 2016) are polyphagous and are considered economic pests in South America (Culik et al., 2007; Hempel, 1912; Kondo et al., 2014). Hitherto, five species of Crypticerya have been recorded in Brazil, namely: C. brasiliensis (Hempel, 1900), C. flava (Hempel, 1920), C. flocculosa (Hempel, 1932), C. luederwaldti (Hempel, 1918) and C. genistae. All of these species are currently only known from the state of São Paulo (Hempel, 1900, $1912,1918,1920)$, with the exception of $C$. genistae which has also been recorded in the state of Espírito Santo (Hempel, 1912; Culik et al., 2007). 
Of the many mealybug species currently known from the Neotropics, the pink hibiscus mealybug (PHM), Maconellicoccus hirsutus (Green, 1908) (Hemiptera: Pseudococcidae) is an invasive species known to cause serious damage to several cultivated and ornamental plants in tropical and subtropical regions around the world. PHM has been reported affecting more than 350 species of host plants from 76 plant families (García et al., 2016). In South America, this mealybug was first observed in Guyana in 1997 (Tambasco et al., 2000), and more recently in Colombia, French Guiana, Suriname and Venezuela (Kondo and Simbaqueba, 2014; Kondo et al., 2012; Morais et al., 2015).

The present paper reports the first records of C. zeteki from Brazil and M. hirsutus from the state of Maranhão, lists their host plants and discusses the importance of these records.

\section{Material and Methods}

Samples were collected in vegetable production areas in the municipalities of São José de Ribamar $\left(02^{\circ} 50^{\prime} 54^{\prime \prime} \mathrm{S}\right.$,

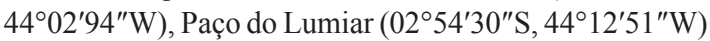
and São Luís $\left(02^{\circ} 60^{\prime} 82^{\prime \prime} \mathrm{S}, 44^{\circ} 27^{\prime} 33^{\prime \prime} \mathrm{W}\right)$ in the State of Maranhão, Brazil. Crypticerya zeteki was collected on branches, leaves and fruits of Citrus spp. (Rutaceae), Cocos nucifera L. (Arecaceae), Cycas revoluta L. (Cycadaceae), Malpighia punicifolia L. (Malpighiaceae), Mangifera indica L. (Anacardiaceae), Musa paradisiaca L. (Musaceae) and Theobroma grandiflorum Schum (Malvaceae). On the other hand, M. hirsutus was collected on leaves, branches, stems and fruits of Annona squamosa L. (Annonaceae), Spondias tuberosa Arruda (Anacardiaceae), T. grandiflorum and M. punicifolia.

The collected specimens were stored in plastic "eppendorf type" tubes in with $70 \%$ ethanol. Later, the specimens were slide-mounted following the method of Gullan (1984) and were identified by the second author (ALBGP) with a compound light microscope. Maconellicoccus hirsutus was identified based on adult female morphology as described by Miller (1999) and Miller et al. (2011), whilst
C. zeteki was identified using the key in Kondo et al. (2012) (for details see Discussion). Duplicate samples of C.zeteki were also sent to the third author (TK) for verification of the initial identification.

\section{Results}

All samples of Crypticerya collected in São José de Ribamar, Paço do Lumiar and São Luís were identified as C. zeteki. They were found on Citrus spp., Cocos nucifera, Cycas revoluta, Malpighia punicifolia, Mangifera indica, Musa paradisiaca and Theobroma grandiflorum, all of which are new host plant records for this species.

The pseudococcid samples collected in Paço do Lumiar and São José de Ribamar on leaves, branches, stems and fruits of Annona squamosa, Spondias tuberosa, T. grandiflorum and M. punicifolia were identified as Maconellicoccus hirsutus. Spondias tuberosa and M. punicifolia are new host plant records for $M$. hirsutus.

Based on the specimens collected in Maranhão, the adult female $C$. zeteki measures about 5.4-7.7 $\mathrm{mm}$ long and range in colour from dark orange to almost red, with dark brown legs. They are covered by a thick layer of white wax with series of tufts and filaments, as follows: (i) a long caudal tuft, 6.6-13.5 mm long (Figure 1a, b), (ii) a cephalic tuft (always shorter than the caudal tuft) (Figure 1b), (iii) lateral filaments, with those closest to the caudal tuft longer than the remaining filaments (Figure 1c) and (iv) an ovisac 4.1-8.5 mm long (Figure 1d).

Plants infested by $C$. zeteki showed leaf senescence, stunted growth and poor fruit production, whilst those infected by $M$. hirsutus showed the 'bunchy-top' deformation symptoms described by Kairo et al. (2000).

\section{Discussion}

Crypticerya zeteki was originally described from samples collected in Panama on an undetermined plant (Cockerell, 1914). More recently, C. zeteki has been reported from Colombia on Dypsis lutescens and Elaeis

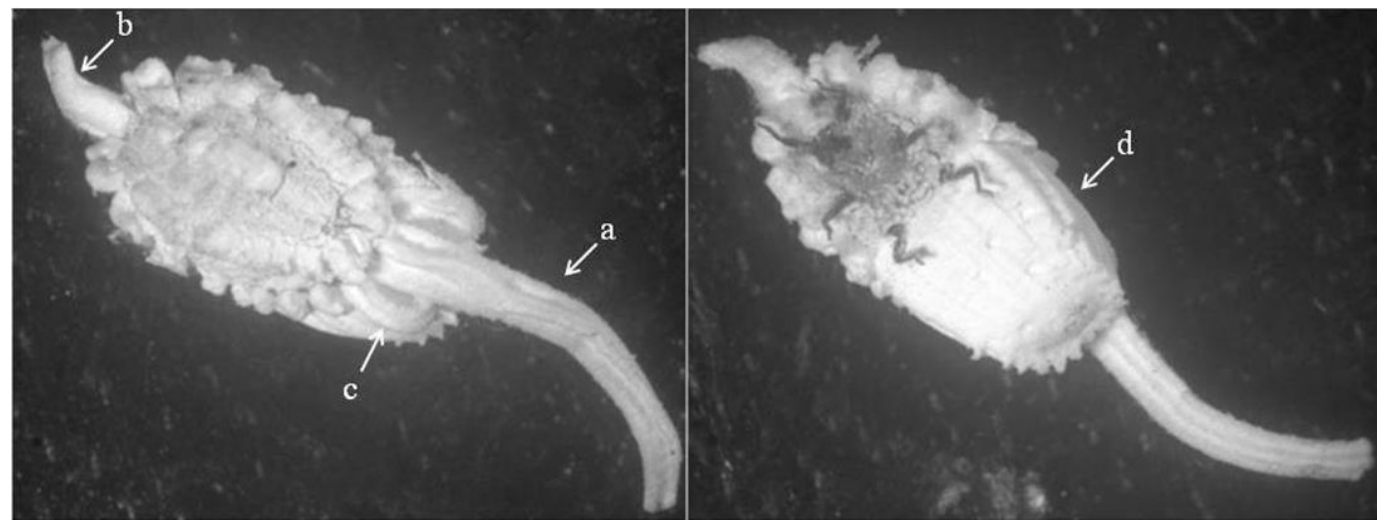

Figure 1. Adult female of C. zeteki, dorsal view (left) and ventral view (right). (a) caudal waxy tuft; (b) cephalic waxy tuft; (c) lateral waxy filaments; and (d) ovisac. 


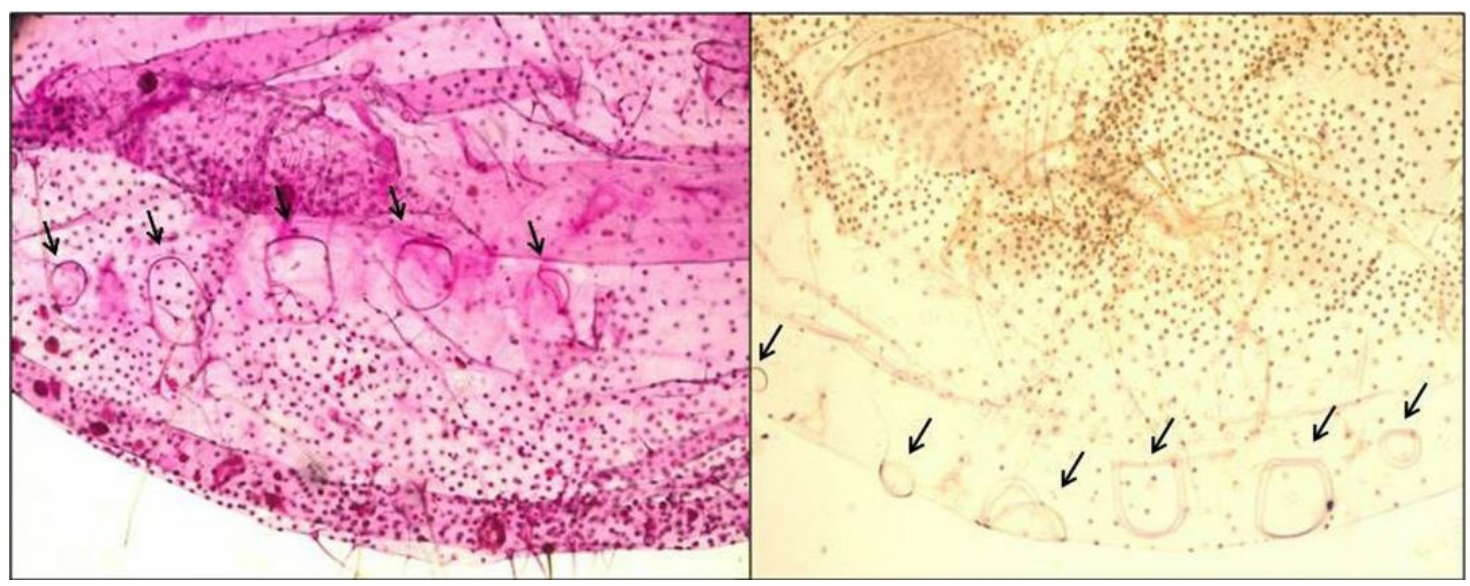

Figure 2. Details of the ventral surface of the posterior end of the abdomen of Crypticerya zeteki showing a specimen with five cicatrices (left) and a specimen with six cicatrices (right).

guineensis (Arecaceae), and Trifolium repens and Arachis pintoi (Fabaceae) (Posada, 1989; Kondo et al., 2016). Crypticerya zeteki is the sixth species of this genus to be recorded in Brazil.

Of the five species of Crypticerya previously reported in Brazil, C. brasiliensis and C. luederwaldti are very similar to C. zeteki (Figure 1), in having long cephalic and caudal waxy tufts, with the caudal tuft being longer than the cephalic tuft, and with the more caudal lateral waxy filaments longer than the rest of the marginal filaments (Hempel, 1900, 1918; Kondo et al., 2016). Measurements of the waxy tufts of $C$. luederwaldti are not given by Hempel (1918) in the only record of this species. C. genistae lacks the long waxy tufts (Kondo et al., 2016) and $C$. flocculosa has long waxy tufts elsewhere on the dorsum (Hempel, 1932). The wax of $C$. similis has not been described. The cuticular morphology of C.zeteki and C. similis, both described from Panama, is very similar. Kondo et al. (2012) could not differentiate $C$. similis and C. zeteki based on available data and so both species key out at the same couplet in their key. They noted that C. similis and C. zeteki have been separated based on a possible difference in the number of cicatrices, i.e., 5 in C. similis and 7 in C. zeteki (Morrison, 1927; Unruh and Gullan, 2008; Kondo and Unruh, 2009). Thus, according to this view, the Crypticerya species collected in the present study should key out as $C$. similis as the present specimens had 5 cicatrices. However, Kondo et al. (2012) pointed out that, in the original description of C. zeteki (as Icerya zeteki), Cockerell (1914) did not mention the number of cicatrices, and that the type specimens of C. zeteki, (deposited in the Bohart Museum of Entomology, University of California, Davis) have 5 cicatrices, not 7 as reported by Morrison (1927) and by Unruh and Gullan (2008) in their redescription of the species. Thus, according to Kondo et al. (2012), C. similis and C. zeteki both have 5 cicatrices and, therefore, cannot be separated based on this feature alone.
Kondo et al. (2012) also reported a specimen from Panama with 7 cicatrices, and concluded that the number of cicatrices could be a variable feature, perhaps related to body size and suggested the need for further studies to solve this problem. Solving the relationship between $C$. similis and $C$. zeteki was not the scope of their study.

Microscopically, C. zeteki differs from all other Crypticerya species found in Brazil, apart from C. similis, mainly in having five or more cicatrices on the ventral abdomen (Hempel, 1932; Kondo et al., 2012), whereas the other five species have three cicatrices. All specimens seen in this study had five cicatrices apart from one which had six (Figure 2). Due to morphological similarities between C. similis and C. zeteki, we agree with Kondo et al. (2012) that further studies should be undertaken.

Maconellicoccus hirsutus was first recorded in Brazil on Hibiscus rosa-sinensis L. in the state of Roraima (Marsaro Junior et al., 2013) and more recently in Espírito Santo (Culik et al., 2013), São Paulo and Mato Grosso (Morais et al., 2015). In some Northeastern Brazilian States, $M$. hirsutus is already causing economic damage to some crops, such as cacao Theobroma cacao L. and soursop Annona muricata L. in Alagoas (Broglio et al., 2015). Maconellicoccus hirsutus is the only species of this genus recorded for South America (García et al., 2016).

In addition to the record of $C$. zeteki from Brazil and the distribution expansion of the M. hirsutus, now including the State of Maranhão, this study contributes to the knowledge of new host plants for both coccoid species. It is the second record of C. zeteki which no host plants were known until now. Furthermore, S. tuberos $a$ and M. punicifolia are recorded as new hosts of the M. hirsutus.

\section{Acknowledgements}

Many thanks to Dr. Penny Gullan (The Australian National University, Canberra, Australia) and to Dr. C. J. Hodgson (Department of Biodiversity and Biological Systematics, 
The National Museum of Wales, Cardiff) for reviewing the manuscript. To Fundação de Amparo à Pesquisa e ao Desenvolvimento Científico e Tecnológico do Maranhão - FAPEMA (Process: BIC-02536/12).

\section{References}

BROGLIO, S.M.F., CORDERO, E.P., SANTOS, J.M. and MICHELETTI, L.B., 2015. Registro da Cochonilha-Rosada-doHibisco infestando frutíferas em Maceió, Brasil. Revista Caatinga, vol. 28 , no. 2 , pp. 242-248.

COCKERELL, T.D.A., 1914. Descriptions and records of Coccidae. II. Non-diaspine subfamilies. Bulletin of the American Museum of Natural History, vol. 23, pp. 331-333.

CULIK, M.P., MARTINS, D.S., VENTURA, J.A., PERONTI, A.L.B.G., GULLAN, P.J. and KONDO, T., 2007. Coccidae, Pseudococcidae, Ortheziidae, and Monophlebidae (Hemiptera: Coccoidea) of Espírito Santo, Brazil. Biota Neotropica, vol. 7, no. 3, pp. 61-65. http://dx.doi.org/10.1590/S1676-06032007000300006.

CULIK, M.P., MARTINS, D.S., ZANUNCIO JÚNIOR, J.S., FORNAZIER, M.J., VENTURA, J.A., PERONTI, A.L.B.G. and ZANUNCIO, J.C., 2013. The Invasive Hibiscus Mealybug Maconellicoccus hirsutus (Hemiptera: Pseudococcidae) and its Recent Range Expansion in Brazil. The Florida Entomologist, vol. 96, no. 2, pp. 638-640. http://dx.doi.org/10.1653/024.096.0234.

GARCÍA, M., DENNO, B., MILLER, D.R., MILLER, G.L., BEN-DOV, Y. and HARDY, N.B., 2016. [viewed 2 December 2015]. ScaleNet: a literature-based model of scale insect biology and systematic [online]. Available from: http://scalenet.info

GULLAN, P.J., 1984. A revision of the gall-forming coccoid genus Apiomorpha Rübsaamen (Homoptera: Eriococcidae: Apiomorphinae). Australian Journal of Zoology, vol. 32, no. 97, pp. 1-203. http://dx.doi.org/10.1071/AJZS097.

HEMPEL, A., 1900. Brazilian coccids. Revista do Museu Paulista, vol. 4, pp. 365-537.

HEMPEL, A., 1918. Descriptions of seven new species of coccids. Revista do Museu Paulista, vol. 10, pp. 193-208.

HEMPEL, A., 1920. Descriptions of new and little known coccids. Revista do Museu Paulista, vol. 12, pp. 329-377.

HEMPEL, A., 1932. Descriptions of 22 new species (Hemiptera - Homoptera). Revista de Etologia, vol. 2, pp. 310-339.

HEMPEL, A., 1912. Catalogs of the Brazilian Fauna. São Paulo: Museu Paulista. $77 \mathrm{p}$.

KAIRO, M.T.K., POLLARD, G.V., PETERKIN, D.D. and LOPEZ, V.F., 2000. Biological control of the hibiscus mealybug, Maconellicoccus hirsutus Green (Hemiptera: Pseudococcidae) in the Caribbean. Integrated Pest Management Reviews, vol. 5, no. 4, pp. 241-254. http://dx.doi.org/10.1023/A:1012997619132.

KONDO, T. and SIMBAQUEBA, C.R., 2014. Sarucallis kahawaluokalani (Kirkaldy) (Hemiptera: Aphididae), a new invasive aphid on San Andres island and mainland Colombia, with notes on other recent invasive species. Insecta Mundi, vol. 0362, pp. 1-10.
KONDO, T. and UNRUH, C.M., 2009. A New Species of Crypticerya Cockerell (Hemiptera: Monophlebidae) from Colombia, with a Key to Species of the Tribe Iceryini Found in South America. Neotropical Entomology, vol. 38, no. 1, pp. 92-100. http://dx.doi. org/10.1590/S1519-566X2009000100009.

KONDO, T., GULLAN, P. and GONZÁLEZ, G., 2014. An Overview of a Fortuitous and Efficient Biological Control of the Colombian fluted scale, Crypticerya multicicatrices Kondo and Unruh (Hemiptera: Monophlebidae: Iceryini), on San Andres island, Colombia. Acta Zoologica Bulgarica, vol. 6, suppl., pp. 87-93.

KONDO, T., GULLAN, P. and RAMOS-PORTILLA, A.A., 2012. Report of new invasive scale insects (Hemiptera: Coccoidea), Crypticerya multicicatrices Kondo and Unruh (Monophlebidae) and Maconellicoccus hirsutus (Green) (Pseudococcidae), on the islands of San Andres and Providencia, Colombia, with an updated taxonomic key to iceryine scale insects of South America. Insecta Mundi, vol. 0265, pp. 1-17.

KONDO, T., GULLAN, P., PERONTI, A.L.B.G., RAMOSPORTILLA, A.A., CABALLERO, A. and VILLAREALPRETELT, N., 2016. First records of the iceryine scale insects Crypticerya brasiliensis (Hempel) and Crypticerya genistae (Hempel) (Hemiptera: Monophlebidae) for Colombia. Insecta Mundi, vol. 0480, pp. 1-9.

MARSARO JÚNIOR, A.L., PERONTI, A.L.B.G., PENTEADODIAS, A.M., MORAIS, E.G.F. and PEREIRA, P.R.V.S., 2013. First report of Maconellicoccus hirsutus (Green, 1908) (Hemiptera: Coccoidea: Pseudococcidae) and the associated parasitoid Anagyrus kamali Moursi, 1948 (Hymenoptera: Encyrtidae), in Brazil. Brazilian Journal of Biology $=$ Revista Brasileira de Biologia, vol. 73, no. 2, pp. 413-418. http://dx.doi.org/10.1590/ S1519-69842013000200024.

MILLER, D.R., 1999. Identification of the Pink Hibiscus Mealybug, Maconellicoccus hirsutus (Green) (Hemiptera: Sternorrhyncha: Pseudococcidae). Insecta Mundi, vol. 13, pp. 189-203.

MILLER, D.R., RUNG, A., VENABLE, G.L. and GILL, R.J.,2011. [viewed 10 June 2016]. Scale insects: identification tools for species of quarantine importance. Scale Families. ARS \& APHIS, USDA. [online]. Available from: http://www.sel.barc.usda.gov/ ScaleKeys/ ScaleInsectsHome/ScaleInsectsFamilies.html

MORAIS, E.G.F., PERONTI, A.L.B.G., MARSARO JÚNIOR, A.L. and AMARO, G.C., 2015. Cochonilha-rosada, Maconellicoccus hirsutus (Green). In: E.F. VILELA, R.A. ZUCCHI, eds. Pragas introduzidas no Brasil: insetos e ácaros. Piracicaba: FEALQ, pp. 21-24.

MORRISON, H., 1927. Descriptions of new genera and species belonging to the coccid family Margarodidae. Proceedings of the Biological Society of Washington, vol. 40, pp. 99-109.

POSADA, L.O.,1989. Lista de insectos dañinos y otras plagas en Colombia. Bogotá: Instituto Colombiano Agropecuario. 662 p.

TAMBASCO, F.J., SÁ, L.A.N., NARDO, E.B.A. and TAVARES, M.T., 2000. Cochonilha rosada, Maconellicoccus hirsutus (Green): uma praga de importância quarentenária já se encontra na Guiana Inglesa. Floresta, vol. 30, no. 12, pp. 85-93. http:// dx.doi.org/10.5380/rf.v30i12.2327.

UNRUH, C.M. and GULLAN, P.J., 2008. Identification guide to species in the scale insect tribe Iceryini (Coccoidea: Monophlebidae). Zootaxa, vol. 1803, pp. 1-106. 